\title{
THE EVOLUTION OF CASTORIDS (MAMMALIA, RODENTIA) IN THE REPUBLIC OF MOLDOVA
}

\author{
Viorica Pascari \\ Institute of Zoology, Chişinău, Republic of Moldova, e-mail: pascaruviorica@gmail.com
}

\begin{abstract}
Beavers first appear in Asia, where fossil remains date back to the Eocene (33-36 million years ago). The most widespread Pleistocene giant beaver fossils were Siberian beavers - Trogontherium cuvieri and the North American beaver - Castoroides ohioensis. According to recent research, the oldest beavers in the Republic of Moldova are known from the deposits of Sarmatian (11.5 million years) - Steneofiber aff. depereti Mayeri, Chalicomys jaegeri (Kaup), Palaeomys castoroides Kaup, Trogontherium minutum minutum Franzet et Storch., T. minutum rhenanum Franzet et Storch. and Monosaulax cainarensis Lungu. In the Meotian (8.7-5.0 million years) only two species were recorded - Trogontherium minutum rhenanum Franzet et Storch. and Castor aff. praefiber Deperet. et Lungu.
\end{abstract}

\section{Introduction}

The only and skilled architect-rodent is the beaver, being one of the largest rodents by weight and length, in the northern part of the Globe, reaching over 30 kilograms in weight and body length up to one meter. Its merit is due to its intense work on the amazing, strange and skilful constructions of dams (plateaus) built of branches, trunks and mud, as a result of which whole rows of trees disappear on the waterfront.

\section{Material and methods}

Paleontological research has been conducted on beaver materials from the time period 11.5 million years ago to the present. The paleontological materials collected by the author and the collections of the Paleontological Museum of the Institute of Zoology (Museum of Fossil Wildlife Complexes from the Republic of Moldova) were used.

\section{Resuls and discussions}

On the territory of the Republic of Moldova the oldest discoveries of skeletal reminiscences of beavers were recorded at the age of about 11.5 million years ago from the middle Sarmatian, lower phase of the Upper Pleistocene, "Moldavian" faunistic complex. From the archaic alluvial deposits from Tătăreşti, Cahul district are known to the following species of fossil beavers: Monosaulax savinovi Lutchev (a P4 premolar tooth with a length of $5.7 \mathrm{~mm}$ and a width of 4.1 $\mathrm{mm}$ ) [5]; Monosaulax cf. munutus (Meyer) from the alluvium from Etulia, UTA Gagauzia - a P4 premolar, $6.8 \mathrm{~mm}$ long and $7.9 \mathrm{~mm}$ wide [18]. From Musaitu, Taraclia district comes the species Trogontheruim aff. minus New., from which the following original pieces: a fragment of the damaged cranial box and the upper jaws with the teeth, P4-M2 on both branches (the length of the dental row on the occlusal surface is $13.8 \mathrm{~mm}$ dex. and $13.6 \mathrm{~mm}$ sin.; a premolar - P4 dex. with a length of $6.0 \mathrm{~mm}$ and a width of $6.2 \mathrm{~mm}$ sin.; a second fragment of the left branch of the upper jaw with teeth P4-M2 (the length of the dental row being $16.2 \mathrm{~mm}$, the 
length of the premolar P4 being $6.5 \mathrm{~mm}$, and the width $-6,8 \mathrm{~mm}$, the dimensions of the upper molars having: M1 - length $8.9 \mathrm{~mm}$, width $4.9 \mathrm{~mm}$, and M2 - length $9.0 \mathrm{~mm}$ and width 5.2 $\mathrm{mm})[16 ; 4]$.

From the alluvial deposits of the Upper Pleistocene, the late phase (17,000-11,000 years ago) which is attributed to the Haprovean Faunistic Complex, were collected: from Etulia, UTA Gagauzia, from the ravines, natural monument, upper layer, ninth terrace of the Prut river - a fragment of the upper jaw of beaver Trogontherium aff. minus New with teeth: the premolar P4 and the molar M1 slightly damaged, the length of the premolar P4 being $7.4 \mathrm{~mm}$, and the width $-9.0 \mathrm{~mm}$.

From the pebble quarries, from Salcia, Anenii Noi district, fossils of Trogontherium cf. cuvieri were collected: from the lower layer a lower beaver jaw of Trogontherium cf. cuvieri Fisch. (straight branch, without anterior part and ascending branch, with teeth M1-M3; an incisor fragment (original piece) with a length of $8 \mathrm{~cm}$, the anterior-posterior diameter (vertical) following the cutting surface being $8.0 \mathrm{~mm}$, the lateral diameter in the same place being 10.0 $\mathrm{mm}$. Fossils of Trogontherium cf. cuvieri Fischer - a lower jaw, straight branch, without anterior and ascending portions with teeth P4-M3, was also discovered in the pebble quarry from Vadul-lui-Vodă, the ninth terrace of the Dniester [8; 15].

In the upper layer of alluvium from the Salcia quarry, Anenii Noi district, Lower Pleistocene, Odesan Faunistic Complex (Psecupsian), 2.58-1.8 million years, a lower jaw, straight branch, was discovered by the beaver Trogontherium cuvieri Fisch. The ascending part of this part is damaged, the dentition is complete (P4 - M3), almost entire incisor (slightly damaged posterior end), its length is $148 \mathrm{~mm}$, the antero-posterior diameter behind the cutting surface is $13.0 \mathrm{~mm}$, the medial-lateral diameter is $10.5 \mathrm{~mm}$.

From the alluvial deposits of the VIII terrace of the Prut, from the ravines from Cismichioi, ATU Gagauzia, which dates back to the age of the Lower Pleistocene and in which a variety of rodent fauna was discovered, only Castoridae gen. sp. and a P4 premolar of beaver Trogontherium sp., with length $7.3 \mathrm{~mm}$ and width $-7,8 \mathrm{~mm}$.

In the pebble of the 7 th terrace of the Dniester, the Tamanian faunal complex from Copanca village, Causeni district a lower jaw was discovered, the left branch of Trogontherium cuvieri Fisch. The ascending (anterior) part is damaged, the teeth are present P4 - M3 and the anterior portion of the incisor well developed - posteriorly following the cutting surface being $13.5 \mathrm{~mm}$ and the lateral diameter $11.0 \mathrm{~mm}$.

V. A. Topacevskii after a tooth fragment from the alluvium from Tiraspol (Colcot's Rock) established its presence of Castor aff. fiber) [13]. Other beaver fossils from Middle Pleistocene deposits in the Republic of Moldova have not been found.

In the Upper Pleistocene, the beaver species Castor fiber L. appears, Upper Paleolithic (42,000-10,000 years ago), which continued into the Holocene (10,000 - present). Skeletal remains (incomplete jaws, isolated teeth, limb bones), which have been discovered at several resorts of prehistoric people, of various archaeological cultures, show that this beaver was hunted, especially for its beautiful fur, flesh and castorine - a dark, fragrant oily liquid, secreted 
from the gland under the tail, used in folk medicine as a good and precious remedy.

The following Paleolithic resorts are known from the Upper Pleistocene, where beaver bones were found:

Duruitoarea Veche, Lower Paleolithic, Axel culture - 44/7 (35,000-10,000 years ago) here and below the counter - skeletal remains, to the denominator - the number of individuals) [9; 3]; the late Paleolithic, the Stone Age ends with the Mesolithic period (10,000-7,000 years ago).

Buteşti, cave, Mustie culture - 1 [13]; Duruitoarea Veche, Madlen culture - 16/4 [9; 2]; Brânzeni I, Upper Paleolithic, Szelet culture (Brânzeni) - 8/3 [9; 2]; Brânzeni I, Mesolit - 2/1 [17; 9]; Trinca I, Mesolit - 2/1 [11].

Most localities from the Republic of Moldova, where skeletal remains of river beaver were found, belong to the Middle Holocene (42,000-8,200 years ago), being recorded at Neolithic (years) and Eneolithic archeological resorts; to the Neolithic resorts; Bugo-Nistrean culture, near the city of Soroca (Soroca I, Soroca II, Soroca III, Soroca V) were discovered 22 skeletal remains from 8 individuals $[1,10]$.

Insignificant skeletal reminiscences of beaver were also collected from other Neolithic resorts: Floreşti, band-linear pottery culture - 4/2 [19; 20], Selişte, Orhei district, culture Criş 3/1, [10]; Sacareuca, Teleneşti district, Criş culture - 1; Floreşti I, Boian culture - 24/12 [20].

Most beaver fossil finds from the Middle Holocene date to Eneolithic archeological sites, Tripolie culture (IV-III millennia BC e. n.), listed below:

Early Trypillia culture: Floreşti, 36 skeletal remains from 17 individuals [20] Rogojeni I, Floreşti district - 4/2 [10]; Floreşti III - 4/2 (unical pieces); Alexandrovca, Floreşti district - 2/1 [10]; Putineşti I, Floreşti district - 2/1 [10]; Ruseştii Noi, Ialoveni district - 10/3 [14]; Solonceni I, Rezina district - 5/2 [7; 10]; Holercani I, Dubăsari district - 1 [20];

Middle Trypillia culture: Solonceni II, Rezina district - 2/2 [20; 10]; Gura Căinarului, Floreşti district - 1 (unical pieces);

Late Trypillia culture: Costeşti II, Râşcani district - 1 [10]; Costeşti IV, Râşcani district 63/29 [10]; Brânzeni III, Edineţ district - 8/3 [21; 10]; Brânzeni IV, Edineţ district - 1, [8]; Iablona I, Glodeni district - 3/1 (unical pieces);

Trypillia culture: Mereşovca-Cetăţuie, Ocniţa district - 8/2 [12]. Lonely beaver graves were found at the resorts Gumelniţa (III-II millennia BC e. n.) from the southwest of the Republic of Moldova; Vulcăneşti II, UTA Găgăuzia - 3/1 [10] and Taraclia, Taraclia district - 1 (unical pieces), in the lats years the species appeared of the Lower Prut meadow [6].

The research was carried out within the state institutional project 20.80009.7007.02

\section{Conclusions}

The first beaver fossils on the territory of the Republic of Moldova were found about 11.5 million years ago (Middle Sarmatian). Later, during the Pliocene and Quaternary (Late Pleistocene, four million years ago), the wooded banks of rivers waters run from Moldova lived species of beavers: Monosaulax savinovi Lutchev, Monosaulax cf. minutus (Meyer), Trogonthe- 
rium aff. minus New., Trogontherium cf. cuvieri Fisch and Trogontherium cuvieri Fisch. In the Upper Pleistocene, Upper Paleolithic, which continued into the Holocene (42,000-10,000 years ago), the river beaver species Castor fiber L. appears. It's been gone for centuries (the middle of the second millennium of our era), then appeared in the last years in the meadow of the Lower Prut.

\section{Bibliography}

1. David A. The mammalian fauna from Mesolithic and Neolithic settlemrnts from Moldova. From the Mesolithic to the Neolithic. Proceedings of the International Archaeological Conference held in the Damjanich Museum of Szolnok, September 22-27, 1996. Budapest 2001.p.167175.

2. David A. Teriofauna formation in the Late Pleistocene and Holocene on the territory of the Republic of Moldova. The Holocene History of the European Vertebrate Fauna - Modern Aspect of Research. Berlin: 1999 p. 9-72.

3. David A Pascaru. V. Castorii (Mammalia, Rodentia, Castoridae Gray, 1821) Pliocen Cuaternarului din Republica Moldova. Diversitatea, valorificarea raţională şi protecţia lumii animale. Materialele Simpozionului internaţional consacrat celeide-a 70 -a aniversări din ziua naşterii profesorului universitar Andrei Munteanu, Chişinău, 2009, p. 288-292.

4. David A., Pascari V. Upper Palaeolithic mammals from Duruitoarea Veche Cave, Republic of Moldova. Ninth Romanian Symmposium on Paleontology. Iaşi, 2013, p. 25-26.

5. Lungu A. Contribution to study the family Castoridae (Rodentia Mammalia) from the Late Miocene of the Republic of Moldova. Probleme actuale ale protecţiei şi valorificării durabile a diversităţii lumii animale. Chişinău, 2007, p.214-216.

6. Munteanu A., Paladi V., Cassir P. Castorul (Castor fiber L., Castoridae) în rezervaţia „Prutul de Jos”, Republica Moldova. Buletinul ştiinţific. Revistă de etnografie, Ştiinţele Naturii şi Muzeologie. Serie nouă. Volumul 32 (45). Ştiinţele naturii. Chişinău, 2020, p. 49-52.

7. Бибикова В.И., Из истории голоценовой фауны позвоночных Восточной Европы Природная обстановка и фауны прошлого., вып. 1, Киев 1963Б с. 117-146.

8. Давид А.И., К вопросу о распространения речного бобра (Castor fiber) в Молдавии. Изв. АН МССР. № 10, 1966, с. 16-19.

9. Давид А.И. Териофауна плейстоцена Молдавии. Кишинев 1980, 186 с.

10. Давид А.И., Формирование териофауны Молдавии в Антропогене Кишинев, Штиинца, 1982, 152 c.

11. Давид А.И. Остатки млекопитающих из раскопок палеолитической стоянки Тринка I. Фауна и флора позднего кайнозоя Молдавии. Кишинев, Штиинца 1985, с.5.

12. Давид А.И. Новые материалы по среднеголоценовой фауне Молдавии. Плиоценантропогеновая фауна днестровского-прутского междуречья. Кишинев, Штиинца 1986, c. 6 .

13. Давид А.И., Верещагин Н.К., Состояние изученности и дальнейшие задачи исследований ископаемых фаун млекопитающих Молдавии. Место и значение ископаемых млекопитающих Молдавии в кайнозое СССР. Кишинев, 1967, с. 10-57.

14. Давид А.И., Маркевич В.И., Хозяйство и фауна неолитических поселений среднего Поднестровья. Фауна кайнозоя Молдавии. Кишинев, 1970, с. 53-74.

15. Давид А. И. Шушпанов К.И. Остатки млекопитающих из неогеновых отложений Молдавии. В кн. Позвоночные неогена и плейстоцена Молдавии. Кишинев, Штиинца, 1972, с.3-18.

16. Давид А.И. Шушпанов К.И. Остатки млекопитающих из среднеплиоценовых отложений у с. Мусаит. Плиоцен-антропогеновая фауна днестровского-прутского междуречья. Кишинев, Штиинца 1986, с.21-34. 
17. Лозан М. Н. Грызуны Молдавии. Т.1, Кишинев: Издательство АНМ, 1970, 168 с.

18. Шушпанов К., Медяник С., 1986 Грызуны и растительность среднего и верхнего плиоцена у с. Етулия. Плиоцен-антропогеновая фауна Днестровского-Прутского междуречья. Кишинев, 1986, с. 34-42.

19. Цалкин В, И., Млекопитающие древней Молдавии. Бюлл.МОИП, отдел биологии. Т. LXVII (5), 1962, с. 36-49.

20. Цалкин В, И., Древнейшие домашние животные Восточной Европы. Москва, 1970, 280 с.

21. Чемыртан Г.Д. Остатки млекопитающих из позднетрипольского поселения БрынзеныЦиганка. Фауна позднего кайнозоя междуречья. Днестр-Прут. Кишинев, Штиинца 1978 , c.54-75. 